\title{
PROFESIONALISME APARATUR PEMERINTAH DAERAH DALAM PENGEMBANGAN KUALITAS KINERJA YANG LEBIH BAIK DALAM MEWUJUDKAN PEMERINTAHAN YANG BAIK
}

\author{
OLEH: ELBERT AGUSTA \& IMANUEL JAYA
}

\begin{abstract}
Abstrak
Dalam upaya pelayanan aparatur pemerintah daerah perlu adanya peningkatan SDM (Sumber Daya Manusia) sarana dan prasarana perlu ditingkatkan sehingga bisa memberikan pelayanan yang terbaik dan berkualitas. Dalam hal ini kita ketahui kinerja aparatur pemerintah daerah ini masih banyak yang perlu dibenahi Rendahnya profesionalisme dan kompetensi PNS Masih banyaknya tumpang tindih kewenangan antar instansi, aturan yang tidak sinergis dan tidak relevan dengan perkembangan aktual,dan masalah-masalah lainya. Persoalan reformasi birokrasi, perbaikan pelayanan publik atau good governance (pemerintahan yang baik) selalu dikaitan dengan Pegawai Negeri Sipil (PNS) yang pengelola administrasi negara. Good Governance adalah tata pemerintahan yang baik, bersih dan berwibawa dengan menitikberatkan pemerintah yang bersih (clean government) dan bebas KKN.
\end{abstract}

\section{Kata Kunci : aparatur, pemerintah, kinerja, kualitas, kebijakan pembangunan}

\section{PENDAHULUAN}

Tuntutan perubahan sering ditujukan kepada aparatur pemerintah menyangkut pelayanan publik yang diberikan kepada masyarakat. Satu hal yang hingga saat ini seringkali masih menjadi masalah dalam hubungan antara rakyat dan pemerintah di daerah adalah dalam bidang public service (pelayanan umum), terutama dalam hal kualitas atau mutu pelayanan aparatur pemerintah kepada masyarakat. Pemerintah sebagai service provider (penyedia jasa) bagi masyarakat dituntut untuk memberikan pelayanan yangsemakin berkualitas. Apalagi dalam menghadapi kompetisi di era globalisasi, kualitas pelayanan aparatur pemerintah akan semakin ditantang untuk semakin optimal dan mampu menjawab tuntutan yang semakin tinggi dari masyarakat, baik dari segi kualitas maupun dari segi pelayanan. Pelayanan publik pada dasarnya menyangkut hubungan antara lembaga pemberi jasa pelayanan dengan masyarakat yang membutuhkan. Dalam rangka penyelenggaraan pemerintah daerah yang sesuai dengan amanat UUD 1945 maka pemerintah pusat memberikan kewenangan kepada pemerintah daerah untuk mengatur dan mengurus sendiri urusan kepemerintahannya. Untuk menciptakan terwujudnya kesejahteraan masyarakat pemerintah daerah melakukan strategi melalui pelayanan, pemberdayaan, dan peran serta masyarakat. Salah satu dari strategi pemerintah daerah adalah memberikan pelayanan, dalam penyelenggaraan pemerintah daerah pelayanan yang diberikan kepada masyarakat salah satunya pelayanan publik. Pelaksanaan otonomi daerah yang luas, nyata, dan bertanggung jawab di awal reformasi tidak dapat dipisahkan dari keinginan untuk menciptakan tatanan kepemerintahan yang demokratis, khususnya tatanan kepemerintahan yang lebih banyak memberikan kewenangan kepada daerah dan rakyat untuk mengelola dan mengatasi persoalan daerahnya. Sejak dikeluarkannya UU No.22 Tahun 1999 tentang Pemerintah Daerah, yang kemudian direvisi dengan UU No. 32 Tahun 2004, Pemerintah Daerah secara terus menerus meningkatkan pelayanan publik. 
Dalam meningkatkan pelayanan publik pemerintah daerah diberikan keleluasaan lebih besar untuk merancang dan menentukan sendiri jenis pelayanan yang dibutuhkan oleh masyarakat.

Seiring dengan hal itu tuntutan masyarakat untuk mendapatkan pelayanan yang berkualitas terus meningkat dari waktu ke waktu. Tuntutan tersebut semakin berkembang seiring dengan tumbuhnya kesadaran bahwa warga negara memiliki hak untuk dilayani dan kewajiban pemerintah daerah untuk dapat memberikan pelayanan. Menurut pasal 14 ayat (1) UU No 32 tahun 2004 tentang Pemerintah Daerah yang berbunyi "Urusan wajib yang menjadi kewenangan pemerintahan daerah untuk kabupaten/kota merupakan urusan yang berskala kabupaten/kota meliputi: perencanaan dan pengendalian pembangunan; perencanaan, pemanfaatan, dan pengawasan tata ruang; penyelenggaraan ketertiban umum dan ketentraman masyarakat; penyediaan sarana dan prasarana umum; penanganan bidang kesehatan; penyelenggaraan pendidikan; penanggulangan masalah sosial; pelayanan bidang ketenagakerjaan; fasilitasi pengembangan koperasi, usaha kecil dan menengah; pengendalian lingkungan hidup pelayanan pertanahan; pelayanan kependudukan, dan catatan sipil; pelayanan administrasi umum pemerintahan; pelayanan administrasi penanaman modal; penyelenggaraan pelayanan dasar lainnya; dan urusan wajib lainnya yang diamanatkan oleh peraturan perundang-undangan".

Pelayanan administrasi merupakan kewenangan wajib daerah kabupaten atau kota. Sesuai dengan semangat demokrasi dan upaya penyelenggaraan pemerintah daerah yang bertanggung jawab maka posisi masyarakat lokal harus dipandang sebagai subjek dan mitra utama dalam pembangunan, termasuk dalam hal kebijakan investasi daerah. Tantangan yang dihadapi dalam pelayanan publik bukan hanya menciptakan sebuah pelayanan yang efisien, tetapi juga bagaimana pelayanan juga dapat dilakukan dengan tanpa membeda-bedakan status dari masyarakat yang dilayani. Dengan kata lain, bagaimana menciptakan pelayanan yang adil dan demokratis. Salah satu filosofi dari otonomi daerah adalah semakin mendekatkan pelayanan kepada masyarakat. Oleh karena itu untuk dapat memberikan pelayanan yang baik terhadap masyarakat, selayaknya perlu diketahui terlebih dahulu persoalan-persoalan yang dihadapi oleh masyarakat. Setelah permasalahan pelayanan masyarakat diinventarisir dan dilakukan analisis, maka perlu dilakukan strategi pelayanan yang efektif dan sesuai dengan karakteristik wilayah dan penduduknya. Pada bidang pemerintah, kegiatan pelayanan lebih menyangkut pada kepentingan umum sehingga sering disebut dengan pelayanan publik.

Demikian pula dalam penyelenggaraan suatu pelayanan publik yang berkualitas, hendaknya aparatur negara sebagai abdi masyarakat memberikan pelayanan yang sebaik-baiknya kepada masyarakat. Masyarakat sebagai pengguna pelayanan publik sangat menginginkan pelayanan publik yang cepat, menyenangkan, tidak mengandung kesalahan, mengikuti proses dan prosedur yang telah ditetapkan. Dengan pemberian pelayanan yang baik kepada masyarakat maka pemerintah akan dapat mewujudkan tujuan negara yaitu menciptakan kesejahteraan masayarakat. Pelayanan kepada masyarakat tersebut terintegrasi dalam penyelenggaraan pemerintahan dan pembangunan. Pelayanan publik berhubungan dengan pelayanan yang masuk kategori sektor publik bukan sektor privat. Pelayanan tersebut dilakukan oleh pemerintah pusat, pemerintah daerah dan BUMN/BUMD. Ketiga komponen tersebut menangani sektor publik menyediakan pelayanan publik. Pelayanan yang diberikan oleh pemerintah daerah untuk memenuhi kepentingan publik disebut pelayan publik. (Hanif Nurcholis, 2007:286-290).

Tuntutan masyarakat mengenai perbaikan kualitas pelayanan publik ditanggapi oleh pemerintah dengan serius. Dengan dikeluarkannya UU No.25 Tahun 2009 tentang Pelayanan Publik merupakan salah satu upaya perbaikan pelayanan publik. Selain itu, disebutkan juga 
mengenai standar pelayanan yang merupakan ukuran yang dibakukan dalam penyelenggaraan pelayanan publik yang wajib ditaati oleh pemberi dan penerima pelayanan. Dalam pasal 5 UU No. 25 Tahun 2009 tentang Pelayanan Publik ruang lingkup pelayanan publik meliputi pelayanan barang dan publik dan jasa publik serta pelayanan administratif yang diatur dalam peraturan pemerintahannya sendiri.

Dalam hal menyikapi paradigma perubahan terhadap undang-undang yang telah berlaku saat ini adalah bahwa kemudian diperlukannya kesiapan pemerintah dalam mengimplementasikan apa yang menjadi tujuan dari pencapaian sasaran lembaga-lembaga pemerintah yang ada dan juga bagaimana pemerintah menyiapkan peran-peran yang akan menjalankan amanat yang telah dibebankan dalam undang-undang tersebut. Namun pemerintah khususnya daerah harus melihat terlebih dahulu bagaimana atau sejauh-mana kesiapan tiap-tiap lembaga dalam menyiapkan hal utama yang akan dibenahi. Kalau kemudian kita berbicara mengenahi hal utama apa yang harus dibenahi dalam melakukan kesiapan ini adalah bagaimana kita mepersiapkan sumberdaya aparaturnya karena individu-individu inilah yang akan menjadi subjek maupun objek dalam melakukan perubahan ini karena pembenahan aparatur merupakan komponen utama dalam proses pembangunan daerah.

Untuk itu jika dilihat dalam berbagai kajian dilihat bahwa, kritik masyarakat terhadap semakin buruknya kinerja, produktivitas, serta motivasi aparatur pemerintahan daerah Kabupaten diseluruh Indonesia mulai dari pemerintah level atas hingga pemerintah level paling bawah (kepala kampung) sebagai penyedia layanan (service provider) bagi masyarakat antara lain di sebabkan karena kurangnya kesiapan Sumber Daya Manusia bagi aparatur pemerintahan daerah.

Oleh karena itu, diharapkan pemerintah daerah dapat mengambil langkah-langkah konkrit untuk perbaikan kinerja aparatur pemerintah sebagai penyedia layanan terhadap masyarakat melalui peningkatan kualitas sumber daya aparatur pemerintahan secara profesional dan terencana serta adanya kebijakan-kebijakan khusus dalam meningkatkan kualitas sumber daya aparatur pemerintahan sebagai penyedia layanan(service provider) tersebut.

\section{Rumusan Masalah}

Dilihat dalam berbagai kajian dilihat bahwa, kritik masyarakat terhadap semakin buruknya kinerja, produktivitas, serta motivasi aparatur pemerintahan daerah Kabupaten diseluruh Indonesia mulai dari pemerintah level atas hingga pemerintah level paling bawah (kepala kampung) sebagai penyedia layanan (service provider) bagi masyarakat antara lain di sebabkan karena kurangnya kesiapan Sumber Daya Manusia bagi aparatur pemerintahan daerah.

Oleh karena itu, diharapkan pemerintah daerah dapat mengambil langkah-langkah konkrit untuk perbaikan kinerja aparatur pemerintah sebagai penyedia layanan terhadap masyarakat melalui peningkatan kualitas sumber daya aparatur pemerintahan secara profesional dan terencana serta adanya kebijakan-kebijakan khusus dalam meningkatkan kualitas sumber daya aparatur pemerintahan sebagai penyedia layanan (service provider) tersebut.

Untuk itu, pada kesempatan ini peneliti ingin menekankan dua faktor mendasar yang dapat mempengaruhi peningkatan kualitas kinerja aparatur pemerintah daerah Kabupaten di seluruh Indonesia dalam meningkatkan pemberian pelayanan kepada masyarakat 


\section{Tujuan Penulisan}

Adapun tujuan penelitian ini adalah:

- Mengkaji kebijakan-kebijakan para aparatur pemerintah di daerah rangka dalam pelayanan kepada masyarakat

- Ingin mendalami arti luas pemerintah daerah maupun SDM (sumber daya manusia) ataupun penyelenggarannya dalam menjalankan birokrasi pemerintahan

- Memberikan motivasi kepada para aparatur pemerintah daerah agar kualitas kerjanya lebih baik

\section{Pembahasan}

Dalam rangka mewujudkan sistem pemerintahan yang bersih dan berwibawa serta pelayanan publik yang baik, efisien, efektif dan berkualitas tentunya perlu didukung adanya Sumber Daya Manusia (SDM) aparatur khususnya Pegawai Negeri Sipil (PNS) yang profesional, bertanggungjawab, adil, jujur dan kompeten dalam bidangnya. Dengan kata lain, PNS dalam menjalankan tugas tentunya harus berdasarkan pada profesionalisme dan kompetensi sesuai kualifikasi bidang ilmu yang dimilikinya.

Menteri Pendayagunaan Aparatur Negara dan Reformasi Birokrasi, mengatakan bahwa dari 4,7 juta Pegawai Negeri Sipil (PNS), sebanyak 95\% PNS tidak kompeten, dan hanya 5\% yang memiliki kompetensi dalam pekerjaannya. Pernyataan Menteri Pendayagunaan Aparatur Negara dan Reformasi Birokrasi ini merupakan salah satu bahan introspeksi diri untuk memperbaiki dan meningkatkan kompetensi bagi kalangan PNS, karena PNS berkedudukan sebagai unsur aparatur negara yang bertugas untuk memberikan pelayanan kepada masyarakat secara profesional, jujur, adil, dan merata dalam penyelenggaraan tugas negara, pemerintahan, dan pembangunan. Rendahnya kinerja birokrasi (PNS) tentu akan mengakibatkan rendahnya kualitas pelayanan publik. Gambaran buruknya birokrasi (kinerja PNS yang rendah) disebabkan kurangnya atau bahkan tidak kompetennya sebagian pejabat struktural di lingkungan pemerintah. Dapat dibayangkan kalau seandainya PNS ini tidak memiliki kompetensi, akan berakibat atau berpengaruh terhadap pelayanan kepada masyarakat, misanya pelayanan menjadi lambat, bekerja asal-asalan, tidak maksimal, tidak efisien dan hasilnya tidak sesuai dengan standar operasional prosedur (SOP) yang telah ditentukan.

Untuk mewujudkan SDM aparatur (PNS) yang profesional dan berkompetensi, sebenarnya pemerintah sudah mengupayakan berbagai program dan kegiatan, seperti melakukan reformasi birokrasi, berbagai Diklat dalam jabatan, berbagai Diklat fungsional, berbagai Diklat teknis, workshop, seminar dan kegiatan ilmiah lainnya. sistem birokrasi di Indonesia. Banyak hal yang harus dilakukan oleh Pemerintah dalam rangka reformasi birokrasi. Reformasi birokrasi pada suatu organisasi pada hakekatnya adalah menata, mengubah, menyempurnakan danmemperbaiki birokrasi agar lebih efisin efektif dan lebih produktif. Hal-hal yang harus dilakukan tersebut diantaranya adalah memperbaiki kinerja PNS dalam melaksanakan pelayanan publik, merubah perilaku pejabat untuk menghindarkan tindak pidana korupsi, dan menata jumlah PNS agar disesuaikan dengan pekerjaan yang ada. Sudah saatnya pemerintah memperbaiki dan memiliki program untuk meningkatkan profesionalitas 
dan produktivitas kinerja PNS. Dalam perekrutan dan penyelesaian CPNS, pemerintah harus mempunyai standar baku yang mesti dinilai berdasarkan kompetensi, keahlian, serta profesionalitas mereka sehingga menghasilkan PNS yang benar-benar dapat diandalkan. Dalam reformasi birokrasi ini harus ditinjau ulang mengenai tugas PNS di setiap lembaga. Pemerintah harus meninjau berapa PNS yang benar-benar dibutuhkan dalam setiap institusi sehingga tidak ada lagi yang menganggur. Menurutnya pemerintah belum menyelesaikan berbagai masalah yang muncul seputar birokrasi secara menyeluruh dan belum terlalu memperhatikan PNS. Menurut Miftah Toha (Guru Besar Ilmu Pemerintahan), hanya 40 persen pegawai negeri yang benar-benar bekerja, sisanya hanya sekedar datang kekantor tanpa melakukan pekerjaan yang berarti.

Kemudian di era globalisasi yang penuh persaingan ini, telah terjadi reformasi di berbagai bidang kehidupan sebagai konsekuensi dari pesatnya pembangunan Ilmu Pengetahuan dan Teknologi (IPTEK). Komunikasi dan informasi telah menimbulkan dampak yang signifikan di seluruh aspek kehidupan masyarakat berbangsa dan bernegara. Reformasi pemerintahan yang terjadi di Indonesia telah mengakibatkan terjadinya pergeseran paradigma penyelenggaraan pemerintahan dari paradigma senteralistis ke arah desentralisasi yang ditandai dengan pemberian otonomi yang luas dan nyata kepada daerah dengan diberlakukannya Undang-Undang Nomor 32 Tahun 2004 tentang Pemerintahan Daerah. Berdasarkan Undang-Undang tersebut dimana pemerintah memberikan kepada daerah otonomi yang luas, nyata, dan bertanggung jawab, sehingga kondisi ini merubah konfigurasi penyelenggaraan manajemen pemerintahan di daerah. Pemberian otonomi daerah ini diarahkan untuk mempercepat terwujudnya kesejahteraan masyarakat melalui peningkatan pelayanan, pemberdayaan (empowering), dan peran serta masyarakat dalam menata pembangunan daerah. Disamping itu, melalui otonomi yang luas, daerah diharapkan mampu meningkatkan daya saing dengan memperhatikan prinsip-prinsip demokrasi, pemerataan, keadilan, keistimewaan, kekhususan, serta potensi dan keanekaragaman daerah dalam sistem negara Kesatuan Republik Indonesia.Dalam menyikapi perubahan yang terjadi mengiringi diberlakukannya Undang-Undang dimaksud, diperlukan kesiapan daerah dalam berbagai bidang pembangunan untuk membangun dan mengembangkan potensi daerahnya. Kesiapan daerah dari segi Sumber Daya Manusia khususnya dalam bidang aparatur pemerintahan daerah sebagai subjek dan objek dari pelayanan dan pembangunan daerah, serta dalam bidang pendidikan baik pendidikan formal maupun pendidikan non formal sebagai faktor terpenting dalam proses pembangunan daerah menuju kesejahteraan masyarakat. Artinya dalam hal dalam menyikapi paradigma perubahan terhadap undang-undang yang telah berlaku saat ini adalah bahwa kemudian diperlukannya kesiapan pemerintah dalam mengimplementasikan apa yang menjadi tujuan dari pencapaian sasaran lembaga-lembaga pemerintah yang ada dan juga bagaimana pemerintah menyiapkan peran-peran yang akan menjalankan amanat yang telah dibebankan dalam undang-undang tersebut

Dengan demikian dapat dikatakan berdasarkan analisis yang diuraikan diatas adalah bagaimana untuk meningkatkan kualitas sumberdaya aparatur tidak hanya diperlukan untuk bagaimana merubah individunya saja tetapi juga bagaimana merubah sistem dalam organisasi tersebut atau dengan kata lain dapat dikatakan dapat diawali dengan merubah dari organisasinya dulu karena jika organ-organ dari organisasi tersebut dapat dibenahi terlebih dahulu misalnya aturan-aturan dari organisasi, struktur organisasinya, atau dapat dikatakan pembenahan dalam kelembagaan organisasi tersebut terlebih dahulu karena apa kalau kemudian perubahan pertama kali di lakukan kepada aparaturnya, maka apabila organisasi tersebut tidak mengginginkan untuk berubah maka sama saja dengan akan tidak berguna karena pasti aparaturnya tersebut juga akan secara tidak langsung atau lama kelamaan akan 
mengikuti organisasinya tersebut. Atau kemudian jika pimpinan dalam organisasi tersebut juga tidak menggigkan untuk berubah maka aparatur tersebut juga tidak akan dapat menolak, karena pasti sebagai pimpinan orang tersebut juga menginginkan bagaimana aparatur pegawainya juga mengikuti prosedur yang diterapkan, inilah beberapa hal yang dikuatirkan jika dalam sebuah oranisasi atau lembaga publik pembenahan sumber daya yang dibenahi terlebih dahulu adalah pada aparaturnya karena diyakini mereka tidak akan dapat menghindar dari lingkaran keburukan organisasi

\section{ANALISIS}

\section{Perubahan dan perkembangan kebijakan pembangunan}

RPJM telah mengidentifikasi 11 (sebelas) permasalahan pembangunan yang dihadapi lima tahun kedepan, salah satu diantaranya adalah permasalahan sumber daya manusia aparatur termasuk di dalamnya adalah PNS. Permasalahan tersebut adalah rendahnya kualitas pelayanan umum antara lain karena tingginya penyalahgunaan kewenangan dan penyimpangan, rendahnya kinerja sumber daya aparatur, belum memadainya sistem kelembagaan (organisasi) dan ketatalaksanaan (manajemen) pemerintahan, rendahnya kesejahteraan PNS, serta banyaknya peraturan perundang-undangan yang sudah tidak sesuai dengan perkembangan keadaan dan tuntutan pembangunan. Untuk itu salah satu agenda pembangunan nasional yang disusun adalah Menciptakan Tata Pemerintahan Yang Bersih dan Berwibawa. Upaya untuk mewujudkan hal tersebut, disusun arah kebijakan pembangunan penyelenggaraan negara tahun 2004-2009, yang ditetapkan sebagai berikut:

1. Menuntaskan penanggulangan penyalahgunaan kewenangan dalam bentuk praktik-praktik KKN melalui: Penerapan prinsip-prinsip tata pemerintahan yang baik (good governance), Pemberian sanksi yang berat bagi pelaku KKN, Peningkatan efektivitas pengawasan aparatur, Peningkatan budaya kerja aparatur, Percepatan tindak lanjut hasil-hasil pengawasan;

2. Meningkatkan kualitas penyelenggaraan administrasi negara melalui: Penataan kembali fungsi-fungsi kelembagaan pemerintahan agar dapat lebih memadai, efektif dengan struktur lebih ramping, luwes dan responsif, Peningkatan efektivitas dan efisiensi ketatalaksanaan pada semua tingkat dan lini pemerintahan, Penataan dan peningkatan kapasitas SDM aparatur agar lebih profesional, Peningkatan kesejahteraan pegawai dan memberlakukan sistem karier berdasarkan prestasi, optimalisasi pengembangan dan pemanfaatan e-Government dan dokumen/arsip negara dalam pengelolaan tugas dan fungsi pemerintahan;

3. Meningkatkan keberdayaan masyarakat dalam penyelenggaraan pembangunan. Dua dari tiga arah kebijakan pembangunan nasional penyelenggaraan negara tersebut diatas mengamanatkan dilakukannya upaya-upaya yang difokuskan pada dua aspek pembangunan yaitu aspek kelembagaan dan sumber daya manusia aparatur. Maksud dari arah kebijakan tersebut yaitu agar pembangunan penyelenggaraan negara mampu mewujudkan aparatur yang profesional, aparatur yang akuntabel, dan aparatur yang sejahtera serta kelembagaan yang efisien dan tanggap terhadap perubahan. Dengan terwujudnya kondisiaparatur sebagai tersebut diatas, diharapkan dapat mengantarkan upaya pembangunan nasional penyelenggaraan negara mencapai tujuan agenda pembangunan nasional: Menciptakan Tata Pemerintahan Yang Bersih dan Berwibawa.

Itu sebabnya diperlukan sebuah aturan agar bagaimana nantinya terwujud pemerintahan yang bersih dan akuntabel yang dapat dipantau oleh seluruh masyarakat.

\section{Pesatnya Perkembangan Teknologi Informasi Komunikasi.}


Globalisasi dan revolusi teknologi informasi-komunikasi menjadi tantangan tersendiri bagi birokrasi dalam upaya menciptakan pemerintahan yang baik, pemerintahan yang bersih, dan berwibawa. Pemanfaatan teknologi informasi dalam birokrasi secara tepat guna, dengan didukung kualitas sumber daya manusia yang baik akan mampu meningkatkan efisiensi dan efektivitas birokrasi untuk meningkatkan kinerjanya. Namun demikian apabila ketersediaan sarana tersebut tidak dapat dimanfaatkan secara tepat guna dan tidak didukung dengan sumber daya manusia yang berkualitas baik, maka hal tersebut hanya akan menciptakan inefisiensi dan akan menghambat sistem manajemen secara keseluruhan. Permasalahan klasik kepegawaian yang sering timbul berkaitan dengan kurang berdayanya sistem informasi manajemen kepegawaian adalah :

- Kesalahan data PNS pada surat keputusan mutasi kepegawaian yang ditetapkan oleh pejabat kepegawaian, hal demikian terjadi (pada umumnya) dikarenakan dalam proses pembuatan keputusan tersebut tidak didukung dengan data yang akurat dan mutakhir.

- Belum berdayanya sistem informasi kepegawaian untuk menghadirkan data dan informasi PNS secara cepat, tepat dan akurat, setiap saat diperlukan dalam rangka pembuatan keputusan-kebijakan kepegawaian nasional. Sedangkan pemeliharaan data PNS secara manual kurang dapat mengimbangi percepatan perubahan dan perkembangan lingkungan yang terjadi.

Dalam hal ini agar kinerja yang dihasilkan dapat bermanfaat atau dapat dicapai dengan cepat, tepat dan bermanfaat bagi masyarakat untuk itu para pegawai harus didukung dengan penerapan teknologi dalam hal ini misalnya pengunaan komputer/ laptop. Peran teknologi ini sangat penting disamping untuk mengikuti perkembangan teknologi juga untuk bagaimana memanfaatkan teknologi tersebut untuk kelancaran kerja agar nantinya pekerjaan tersebut dapat terselesaikan dengan cepat dan akurat.Tetapi yang lebih utama adalah bagaimana menerapkan teknologi tersebut dengan benar atau sesuai prosedur agar tidak terjadi penyimpangan dan disalah gunakan.

\section{Peluang Kepegawaian Ke Depan}

Keberadaan Pegawai Negeri Sipil sebagai aparat birokrasi yang berasal dari jalur karier kepegawaian (non political appointees) selalu dijumpai di setiap pemerintahan suatu negara, dan keberadaannya akan terus eksis selama pemerintahan negara tersebut masih ada. Keberadaan PNS dibutuhkan oleh pemerintah dan negara (stakeholder), dimana PNS selaku pelaksana kebijakan untuk menggerakan birokrasi, dan dibutuhkan oleh masyarakat secara umum (customer) dalam wujud pelayanan publik yang diberikan kepada masyarakat (fungsi public service). Oleh karena itu Pegawai Negeri Sipil disebut "public servant atau civil servant," yang selalu dibutuhkan oleh Pemerintah/Negara, dan Masyarakat sebagai pengguna jasa PNS.

Perubahan dari dua faktor utama (pemerintah selaku stakeholder dan PNS selaku pelaksana kebijakan/penyelenggara birokrasi serta penyedia pelayanan kepada masyarakat) diperlukan, karena dipengaruhi oleh dinamika perubahan di berbagai bidang, seperti: POLEKSOS, demografi, dan meningkatnya tuntutan publik kepada PNS, serta pengaruh global. Dari sisi pemerintah, perkembangan dan perubahan lingkungan yang terjadi telah disikapi dengan berbagai upaya penyesuaian arah kebijakan pembangunan nasional. Kebijakan pembangunan penyelenggaraan negara, diarahkan untuk menciptakan Pemerintahan Yang Bersih dan berwibawa sebagaimana tertuang dalam RPJM.Sejahtera, dimana penghasilan PNS dapat memenuhi tingkat hidup layak bagi diri dan keluarganya, yang didukung dengan sistern 
penghargaan non materiil yang adil dan rasional, sehingga mampu menumbuhkan motivasi yang selanjutnya memacu peningkatan kinerja, dan terciptanya aparatur yang bersih dari KKN.

Sedangkan penyesuaian yang harus dilakukan oleh kepegawaian adalah menyelaraskan program-program kepegawaian dengan arah kebijakan pembangunan nasional serta tuntutan stakeholder (pemerintah) dan masyarakat yang menghendaki terwujudnya PNS yang profesional, dan bersih dari KKN, sehingga mampu menghadirkan pelayanan terbaik bagi masyarakat dan mendorong terciptanya kepemerintahan yang baik (good governance). Untuk itu masih terbuka peluang bagi kepegawaian di masa depan, apabila mampu mengembangkan sistem manajemen kepegawaian yang ada, sehingga dapat mewujudkan PNS sebagaimana diharapkan oleh stakeholder dan customernya.

Sistem manajemen kepegawaian yang berawal dari sistem perekrutan, promosi dan mobilisasi, esolonisasi, renumerasi, pendidikan dan pelatihan, kesejahteraan pegawai, disiplin, dan pensiun. Memerlukan perbaikan manajemen kepegawaian yang terintegral dan komprehensif. Maka hendaknya instansi yang menangani manajemen kepegawaian seperti Kementerian Pendayagunaan Aparatur Negara (menpan), Badan Kepegawaian Negara (BKN), Badan Kepegawaian Daerah (BKD), lembaga Administrasi Negara (LAN) sebagai pengelola PNS untuk bisa duduk bersama memperbaiki manajemen kepegawaian yang lebih baik. Ada beberapa masukan untuk memperbaiki manajemen kepegawaian sebagai berikut :

- Manajemen kepegawaian (PNS) yang cenderung menggunakan system tertutup karena akibat dari desentralisasi dan otonomi daerah, maka perlu dikembalikan ke system manajemen nasional yang terpadu dan terbuka sehingga memungkinkan semua orang bisa memasuki atau menjadi pegawai pemerintah tanpa dihalangi oleh asal usul etnis dan kedaerahannya. Dengan demikian, hal-hal yang bisa dibantu antara lain menata dan mereformasi manajemen kepegawaian secara menyeluruh dengan menggunakan system yang tepat untuk wilayah Indonesia yang luas;

- Pengembangan Pendidikan dan Pelatihan PNS tidak lagi dititkberatkan kepada Diklat Struktural yang cenderung menjadikan orientasi pegawai hanya untuk mendapatkan jabatan struktural, namun Diklat diarahkan untuk meningkatkan keahlian dan kecakapan pegawai;

- Dalam pelaksanaan Otonomi Daerah, pengelolaan Manajemen kepegawaian di daerah dilakukan secara otonom oleh daerah mulai dari rekrutmen sampai dengan pensiun. Perlu adanya restrukturisasi kelembagaan dalam manajemen kepegawaian di daerah tidaknya bersifat administratif, namun perlu struktur kelembagaan baru yang diarahkan dan berorientasi terhadap pengembangan potensi dan profesionalisme pegawai, memberi pelayanan yang opimal kepada masyarakat. Maka perlu kiranya manajemen kepegawaian dibantu melakukan analisis organisasi, analisis jabatan yang tepat bagi pemenuhan kebutuhan peningkatan kompetensi dan profesionalisme pegawai.

\section{Prespektif Perbaikan Kinerja Untuk Mewujudkan Tata Kelola Pemerintahan Yang Baik}

Aparatur negara merupakan salah satu pilar dalam mewujudkan Kepemerintahan Yang Baik (Good Governance). Kepemerintahan yang baik (good governance) bukan hanya konsep yang perlu disosialisasikan, namun perlu diterapkan pada semua level pemerintah di manapun berada. Penerapan konsep good governance untuk kasus pemerintah di Indonesia diamanatkan dalam Ketetapan MPR RI No. IX/MPR/1998 tentang Penyelenggaraan Negara 
Yang Bersih dan Bebas Korupsi, Kolusi, dan Nepotisme. Kemudian pemerintah Indonesia juga mengeluarkan Undang-Undang No. 28 Tahun 1999 tentang Penyelenggaraan Negara yang Bersih dan Bebas dri Kolusi, Korupsi, dan Nepotisme.

Beberapa poin penting yang terkait dengan implementasi prinsip-prinsip Good Governance merupakan pegangan bagi birokrasi publik dalam melakukan transformasi manajemen pemerintahan. Menurut Tjokroamidjojo, tuntutan ke arah Good Governance juga lahir akibat kualitas pelayanan publik yang rendah.

Untuk itu diharapkan adanya penyelenggaraan kepemerintahan yang baik tingkat kompetensi aparatur seperti misalnya dengan memiliki pegangan seperti antara lain:

- Insentif dan responsive terhadap peluang dan tantangan baru yang timbul.

- Tidak terpaku pada kegiatan-kegiatan rutin yang terkait dengan fungsi instrumen birokrasi, akan tetapi harus mampu melakukan terobosan melalui pemikiran yang kreatif dan inovatif

- Mempunyai wawasan yang luas dan jauh kedepan.

- Memiliki kemampuan untuk mengantisipasi, mempertimbangkan dan meminimalkan resiko

- Tanggap terhadap peluang dan potensi yang dapat dikembangkan.

- Memiliki kemampuan untuk menggali sumber-sumber potensial

Disini diharapkan kepada bagaimana sumberdaya aparatur yang dalam hal ini adalah pegawai negeri untuk bagaimana memberikan pelayanan dan kinerja yang betanggung jawab agar bagaimana dapat mencerminkan tata pemerintahan yang baik, dalam hal ini pegawai tidak hanya menunggu apa kemudian langkah yang diambil oleh pemerintah untuk memperbaiki kinerjanya tersebut namun bagaimana para pegawai tersebut nantinya dapat mengambil peluang tersendiri untuk bagaimana memciptakan sebuah terobosan-terobosan yang dapat memperbaiki kualitasnya atau kinerjanya dalam mewujudkan tata pemerintahan yang baik.

\section{KESIMPULAN}

Dari diskusi diatas dapat diambil sebuah kesimpulan yakni bagaimana akan pentingnya sumberdaya aparatur yang dalam hal ini adalah pegawai negeri untuk bagaimana memperbaiki kinerjanya misalnya mulai dari perekrutan pegawai baru, seleksi, penetapan dan pelatihan setelah dan sebelum menjadi pegawai yang selama ini dipandang dalam masyarakat sangat rendah karena kualitas pelayanan, kineja dan profesionalisme yang masih kurang dan terkesan setelah menjadi pegawai mereka tambah malas . banyak masyarakat yang mengeluhkan akan hal ini. Sehingga aparatur pemerintahan ini selalu mendapatkan kritikan, karena inilah para pegawai diharapkan untuk nantinya dapat menciptakan tata kelola pemerintahan yang baik yang sesuai dengan prinsip-prinsip yang tertuang dalam Good Governance, dan ada beberapa hal yang menjadi kunci perubahan sumberdaya aparatur antara lain:

- Besarnya political will/government will secara konsisten, sungguh-sungguh, dan serius dalam pemberantasan KKN serta perubahan mind-set;

- -Meningkatnya kesamaan persepsi dalam tujuan, pola tindak serta rencana;

- Memanfaatkan teknologi informasi (e-gov, e-procurement) dalam pemberantasan KKN;

- $\quad$-Adanya kesepakatan penerapan single identity number (SIN);

- Pembaharuan peraturan perundang-undangan yang tumpang tindih;

- Penataan criminal justice system. 
Dalam hal ini tidak hanya pemerintah tapi aparaturnya yang dalam hal ini adalah pegawai negeri haruslah sudah siap dan benar-benar bersungguh-sungguh untuk merubah kinerjanya dalam berbagai aspek, dalam rangka mewujudkan cita-cita bersama yakni penciptaan tata kelola pemerintahan yang baik bersih dari unsur KKN.

\section{DAFTAR PUSAKA}

Bratakusumah, Otonomi Penyelenggaraan Pemerintahan Daerah. PT. Gramedia, Jakarta. 2002.

Carol S. Dweck, Change Your Mindset Change Your Life, PT Serambi Ilmu Semesta, Jakarta. 2007.

Dwiyanto, Agus, dkk. Mewujudkan Good Governance Melalui Pelayanan Publik. Gajah Mada Press, Yogyakarta. 2006.

Ife, Jim. 1995, Commutity Development, creating community alternatives Visions analisis and practices, Australia : Logman Inc.

Saiful H. Djarot, Manajemen Pelayanan Publik Dalam Pelaksanaan Otonomi Daerah dan Penataan Kelembagaan di Pemerintah.

Sandy Mac Gregor. Piece of Mind, PT Gramedia Pustaka Utama, Jakarta, 2002.

Suhendra.2006, Peran Birokrasi Dalam Pemberdayaan Masyarakat, bandung : Tria Kencana.

Teguh Sulistiyani, Ambar. 2004, Memahami Good Governance Dalam Prespektif Sumberdaya Manusia. 